\title{
Review of Different Prorated Models Which Detects the Effect of Accelerated Stresses on Power Transformer Insulation
}

\author{
Jashan Deep Singh, Yog Raj Sood and Piush Verma
}

\begin{abstract}
Transformer protection and safety is based on large number of tests. On the basis of these test results, vital decision on transformer diagnostic and condition monitoring is done. But some times it is not possible to conduct the tests on transformer in service because it may destructive in nature so, in order to perform these tests, scaled-down or prorated models of actual power transformers are used in experimental study. In this paper, different prorated models with their aging cycles have been studied.
\end{abstract}

Index Terms-- Power transformers, prorated models, thermal models, aging temperature, aging time, oil insulation, paper insulation.

\section{INTRODUCTION}

Liquid-immersed power transformers have utilized an insulation system consisting of natural cellulose-based materials and mineral oil for over 100 years. The transformers insulation is always subjected to stresses such as thermal, electrical or their combinations. These stress acts as a promoter of the chemical reactions $\&$ affects the electrical, chemical and mechanical properties of the insulation. The thermal stress on the insulation system may occur due to discharges, dielectric heating, operation in a high temperature environment, due to Joule heating $\left(I^{2} R\right.$ losses) and iron losses.

The transformer is the most costly equipment of the power system. In order to protect the transformer, it should pass from large number of tests. But, it is well known fact that all of the required tests should not be performed on a power transformer in service because some of these tests are destructive in nature. As the test results of these experiments are vital in diagnostic and monitoring procedure for transformers in actual working conditions. Therefore, in order to perform these tests, scaled-down or prorated models of actual power transformers are used in experimental study (Saha, 1997). In this paper, different prorated models with their aging cycles have been studied.

These models are based on long term and short term accelerated aging. In long term accelerated aging, experiments have been conducted at temperatures in the range 90 to $145^{\circ} \mathrm{C}$ for time periods of up to 100 weeks

Jashandeep Singh, Research Scholar, Electrical Engineering. Dept (EED), NIT Hamirpur, India, (jashanjb@gmail.com)

Y.R.Sood, Prof., EED, NIT Hamirpur, India (yrsood@gmail.com)

Piush Verma, Director, Rayat \& Bahra College of Engg. \& Bio Tech for Women, Kharar, Distt. Mohali -140104 ( Punjab), India (pverma19@yahoo.co.uk) e.g. Montsinger (Montsinger, 1930) conducted experiments at 90 to $110^{\circ} \mathrm{C}$ for up to 70 weeks, Dakin (Dakin, 1948) at 100 to $135^{\circ} \mathrm{C}$ for up to 100 weeks, Shroff et al. (Shroff, 1985) at 110 to $140^{\circ} \mathrm{C}$ for up to 180 days, Moser et al. (Moser,1986) at 90 to $135^{\circ} \mathrm{C}$ for up to 400 days, to predict the long term insulation behavior \& to provide information on the life of insulation system. On the other hand, short term accelerated ageing experiments are conducted at high temperatures in the range 130 to $190^{\circ} \mathrm{C}$ for a short period of time. For example, Oomen (Oomen, 1981) conducted experiments at 120 to $180^{\circ} \mathrm{C}$ for up to 7 days, Moser et al. (Moser, 1986) at 145 to $190^{\circ} \mathrm{C}$ for up to 20 days.

\section{THERMAL MODELS}

The life of transformer depends upon the life of insulating system. In order to predict the life of oil filled power transformer it is vital to understand the insulation system (Saha, 2008). Aging of insulation in power transformers is intimately connected with the magnitude and the duration of the thermal stress on the insulation. It is well known that aging experiments made under normal operating stress conditions in laboratory environment, require inordinately long times before credible failure data can be acquired. This implies a considerable expenditure in terms of time and costs of running aging experiments. Thus to work out a method of acquiring failure data in a much shorter time by judiciously increasing the stresses applied during the aging experiments a carefully designed and controlled laboratory scale experiments shall be performed to assess the causing of premature failure. The nature of the stresses used in laboratory experiment could either be continuous in time or stepped at appropriate levels. The purpose of these experiments is to deliberately introduce conditions favorable for rapid deterioration of insulation and in the course of aging, observe, monitor and quantify the essential properties which cause failure (Pradhan, 2004). The status of insulation can therefore be assessed by monitoring those properties of insulation which are sensitive to the amount of aging. The most sensitive parameters which can serve as indices of aging are DGA, furans, DP, Dielectric Strength (BDV), PD, C \& tan delta, moisture content, different spectroscopic parameters etc (Pradhan, 2006). Some of the important types of model available in literature are described in this paper.

\section{A. Prototype Model}

Prototype model (shown in figure 1) is $5 \mathrm{kVA}, 220 / 5000$ 
$\mathrm{V}, 50 \mathrm{~Hz}, 1-$ phase core type transformers. It incorporating all the essential features of a large transformer (such as LV \& HV windings wound on CRGO steel cores, ON type of cooling, nitrogen cushion of appropriate volume is provided and the units are hermetically sealed from atmosphere). The prorated units are rendered gas-tight by using self-sealing septum arrangement so as to avoid leakage. The model transformers are impregnated and filled with high quality naphthanic based mineral insulating oil. Standard practices for impregnation of cellulose paper have been adopted in the process. The most important criterion in the design of power transformer prototype is the ratio of amount of oil to paper. This ratio is maintained in the neighborhood of $4: 1$. The mechanism of aging shall remain invariant under accelerated stress conditions and during normal operating conditions.

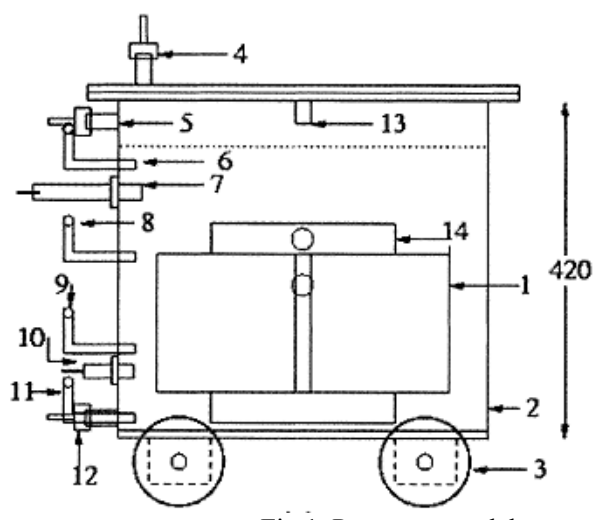

Fig 1. Prototype model

As indicated in prototype model, 1 is winding; 2 is tank; 3 is wheel; 4 is online gas valve; 5 is nitrogen valve; 6 is TOT probe; 7 is $\mathrm{HV}$ bushing; 8 is MOT probe-1; 9 is MOT probe-2; 10 is LV bushing; 11 is BOT probe; 12 is bottom drain valve; 13 is eyelet; 14 is frame.

Aging process in prototype model: Three loading blocks shown in figure 2, are found to be adequate to cause sufficient amount of aging over an experimental duration of about one year. Also, the incremental time duration of these blocks is adjusted such that the amount of aging during each block remains nearly the same, in accordance with the norms of equated aging procedure. Throughout the experimental run, the electrical stress was kept at normal levels (i.e., transformers were operated at rated voltage) (Pradhan 2004, 2006, 2005).

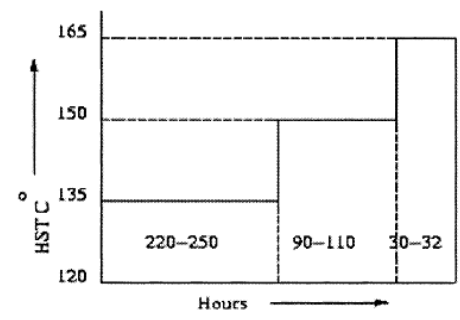

Fig 2. A typical loading cycle

\section{B. Dual Temperature aging Model}

Dual temperature aging model (figure 3) is prepared for simultaneous accelerated ageing of two different solid insulation material immersed in the mineral oil. This model was used to derive test data on a cellulose/ mineral oil system, a Nomex/mineral oil system and on a hybrid Nomex/cellulose/mineral oil system. The conductors were insulated with 4 layers of 3 mil Kraft or 6 layers of 2 mil Nomex, wound in half-laps for a total two-side build of 48 mils (McNutt, 1996).

In T.A.Prevost, R.Wicks et al. dual temperature aging model, the insulated conductor and associated turn spacer insulation can be controlled at one temperature while the bulk oil and its associated barriers type insulation can be controlled at a second temperature. This model is used for measuring tensile strength, degree of polymerization (DP) and furan contents present in the oil. This study also investigating non-thermally upgraded and thermally upgraded conductor insulation to determine the effects of thermal upgrading on insulation aging (Prevost, 2006).

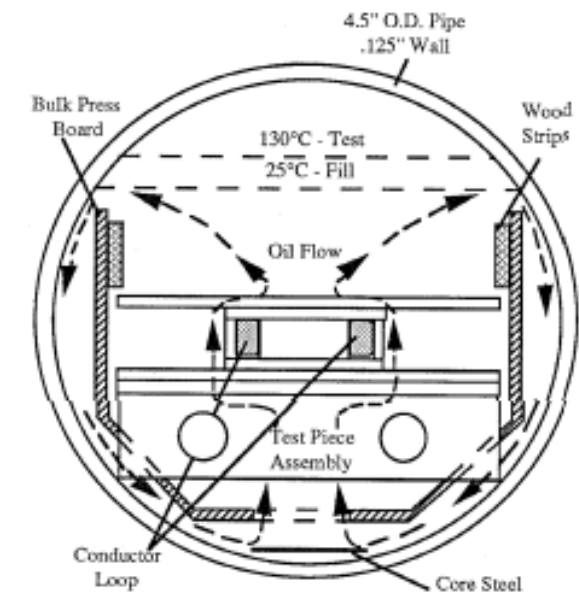

Fig 3. Cross section of Dual Temperature aging Model

Aging process in dual temperature aging model: The test assemblies were oven dried in batches of three at atmospheric pressure in a $110^{\circ} \mathrm{C}-125^{\circ} \mathrm{C}$ oven for a period of 4 - 5 days. Mineral oil was dried separately in an impregnation vessel at $100^{\circ} \mathrm{C}$ under maximum attainable vacuum $(<2 \mathrm{mmHg}$, absolute) for a period of 3-4 days. After oil drying, the impregnation vessel was purged with $\mathrm{N}_{2}$ and a portion of the oil transferred to a holding tank where it was stored under $\mathrm{N}_{2}$ at 2 psig (103 torr) for later use in filling the test cells. The dried insulation assemblies were removed from the oven and quickly transferred to the impregnation vessel where they and the remaining oil were held under maximum vacuum at $100^{\circ} \mathrm{C}$ for approximately 3 hours. The assemblies were then lowered into the oil without breaking vacuum and maintained under vacuum at $100^{\circ} \mathrm{C}$ for 3 - 4 days.

When impregnation of the test assemblies was complete, the empty cells were prepared for loading. Once the test assembly was in place in its cell, the gas space above the oil was purged with $\mathrm{N}_{2}$ at approximately 2 psig (103 torr) for approximately 5 minutes. When purging was complete, the lid was bolted down to seal the cell. The cell was then placed into the test cabinet with connection to the top oil, bottom oil and conductor thermocouple and to the $\mathrm{N}_{2}$ supply, oil heater and the current transformer were made. The $\mathrm{N}_{2}$ supply was set at approximately 2 psig (103 torr) and the thermocouple readings were checked. Samples of both the solid insulation and the mineral oil were tested prior to start up and shut down of each cell. Changes 
between the initial and final states were used to determine the amount of degradation occurs during the testing cycle. At the completion of aging, power to the cell was shut off and two $50 \mathrm{ml}$ syringes of oil (each for DGA and moisture content) were removed while the oil was still hot. After the cell had cooled, but before opening it, another syringe was filled for DGA testing of the cool oil. Upon opening of the cell, the entire test assembly was removed. Samples of bulk insulation, high density board and conductor wrap were taken for testing of moisture content. The samples were double-wrapped in plastic wrap and plastic bags to prevent moisture migration. The insulated conductor was temporarily stored in a pail of clean dry oil.

Test program and Aging temperatures in each of the three types of cell were maintained in accordance with Table 1 and Table 2 respectively.

TABLE 1. TEST PROGRAM

\begin{tabular}{|c|c|c|c|}
\hline Duration & Cellulose & Nomex & Hybrid \\
\hline $500 \mathrm{~h}$ & 3 & 1 & 2 \\
\hline $1500 \mathrm{~h}$ & 2 & 2 & 1 \\
\hline $5000 \mathrm{~h}$ & 1 & 1 & 1 \\
\hline $10000 \mathrm{~h}$ & - & 1 & 1 \\
\hline Totals & 6 & 5 & 5 \\
\hline
\end{tabular}

TABLE 2. AgING TEMPERATURES

\begin{tabular}{|l|l|l|}
\hline Insulation System & $\begin{array}{l}\text { Conductor } \\
\text { temp. }\end{array}$ & $\begin{array}{l}\text { Bulk oil } \\
\text { temp. }\end{array}$ \\
\hline Control: Cellulose/Mineral Oil & $160 \mathrm{deg}$ C & $115 \mathrm{deg}$ C \\
\hline High temp.: Nomex/Mineral Oil & $240 \mathrm{deg}$ C & $130 \mathrm{deg}$ C \\
\hline $\begin{array}{l}\text { Hybrid: } \\
\text { Nomex/Cellulose/Mineral Oil }\end{array}$ & $240 \mathrm{deg}$ C & $130 \mathrm{deg}$ C \\
\hline
\end{tabular}

As the temperature \& aging time increases, the average retained strength decreases. The tensile strength and thermal durability of hybrid systems is excellent as compared to the cellulose system. Oil quality measured by color, acidity and power factor was degraded to a greater extent over time in the cellulose test cells than in the hybrid or Nomex cells, even though temperatures were lower in the cellulose cells. Nomex material can be permitted to reach a higher level (i.e. $170^{\circ} \mathrm{C}$ or more). Mostly Nomex can be used in the equipment for compact size and/or light weight (e.g. mobile transformers, traction transformers, etc.) which can justify the higher cost of the high temperature material (McNutt, 1996).

\section{Ampoules model}

Ampoules model (Saha, 2008) is used for accelerated ageing experiments, as shown in figure 4 . In this model, a section of new insulated conductor $(210 \mathrm{~mm})$ were cut and wrapped with insulating paper, shown in figure 5, and placed in a glass ampoule. The ampoules were approximately $45 \mathrm{~mm}$ in diameter and contained about 230 $\mathrm{ml}$ of oil and 8 conductors per ampoule. Thus the paper to oil ratio was approximately $86 \mathrm{mg} / \mathrm{ml}$. The ampoules were heated in a temperature controlled aluminum heater block, with the variation in the temperature of $\pm 2^{0} \mathrm{C}$ per heating cycle in the block.
Prior to ageing, the conductor samples were dried in a vacuum oven for 24 hours at $80^{\circ} \mathrm{C}$. The conductors were then transferred into the ampoules and evacuated at a pressure of $10^{-3}$ Torr for two days at room temperature and then for 1 hour at $145^{\circ} \mathrm{C}$ for deep moisture removal. Then the ampoules were cooled to room temperature and new Shell Diala B oil was added to the ampoule so that the conductor and paper were completely immersed. The moisture content of the oil was determined by the Karl Fischer titration before addition to the ampoules. Following addition of the oil, the samples were evacuated at $10^{-3}$ Torr for one more day before elevated temperature ageing was commenced and sealed under vacuum.

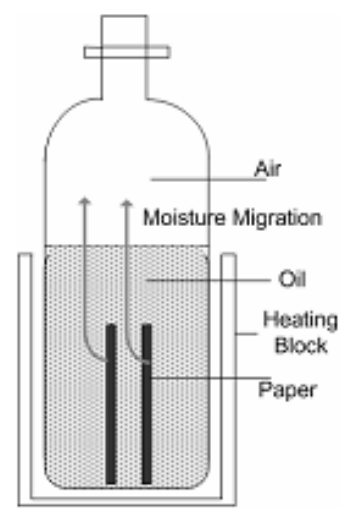

Fig 4. Ampoules model

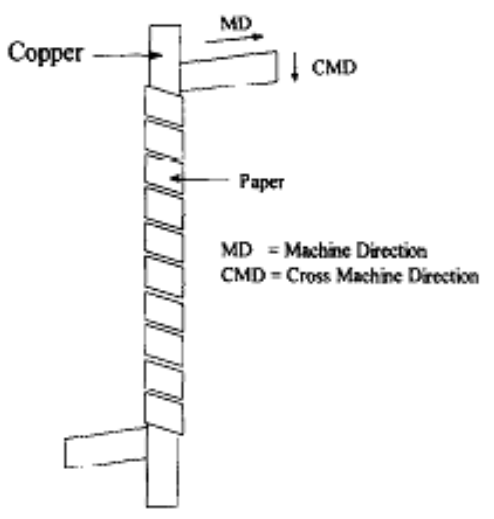

Fig 5. Paper wrapped around a copper conductor.

The accelerated ageing experiments were performed at four different temperatures for various periods of time under air and nitrogen environments. For ageing under nitrogen, dry nitrogen gas was passed continuously over the surface of the oil for the entire arcing time. Thus any water released into the nitrogen would be removed by the gas flow. For arcing in air, the samples were left open to the atmosphere via a silica gel drying tube, but there was no gas flow. Although there was no gas flow over the surface of the oil in the case of the air-aged samples, there was no evidence of a build up of moisture at the surface of the oil, presumably because any evolved water was absorbed by the silica gel drying agent. After ageing, the samples were allowed to cool to room temperature. Paper and oil samples were removed for moisture measurement (Saha, 1999). 
TABLE 3. AGING ACCELERATED EXPERIMENTS-I

\begin{tabular}{|c|c|}
\hline Aging temperature $\left({ }^{\circ} \mathrm{C}\right)$ & Aging time (days) \\
\hline 115 & $42,83 \& 125$ \\
\hline 125 & $22,45 \& 67$ \\
\hline 135 & $12,25 \& 37$ \\
\hline 145 & $7,14 \& 21$ \\
\hline
\end{tabular}

TABLE 4. AgING ACCELERATED EXPERIMENTS-II

\begin{tabular}{|c|c|}
\hline Aging temperature $\left({ }^{0} \mathrm{C}\right)$ & Aging time (days) \\
\hline 129 & $14,21 \& 28$ \\
\hline 138 & $14,21 \& 28$ \\
\hline 153 & $3,7,14 \& 21$ \\
\hline 166 & $3,7,14 \& 21$ \\
\hline
\end{tabular}

In order to perform ageing experiments on paper wrapped insulated conductors in ampoules model different temperature range were selected as shown in Table 3 and table 4. In (Saha, 1999), experiments were performed at temperature range of 115 to $145^{\circ} \mathrm{C}$ in the presence of air and nitrogen environments. In (Hill, 1995, 1996, Saha, 2000), a series of accelerated ageing experiments were performed on dried Kraft insulation paper in the temperature range $130-170^{\circ} \mathrm{C}$ under vacuum in order to examine the thermal degradation process separately from the process of oxidation and hydrolysis by water.

The objectives of these experiments are to study the nature of cellulose and oil degradation, the deterioration of chemical, electrical and mechanical properties and the effect of oxidation on the degradation process. The condition of aged insulation samples was investigated by a number of diagnostic techniques:

1) Measurement of Interfacial Polarization Spectra (IPS) by Return Voltage Method (RVM) at temperature range of 115-1450 C (Saha, 1999, 2000).

2) Measurement of Molecular Weight and its distribution by Ge1 Permeation Chromatography (GPC) at temperature range of 115-1450 C (Saha, 1999, 2000) and 129-1660 C (Hill, 1995) and the results of the molecular weight study in the accelerated ageing experiments were found to be most useful for monitoring the condition of the insulation paper in an operational transformer.

3) Surface analysis by X-Ray Photo-Electron Spectroscopy (XPS) at temperature range of 115-1450 C.

4) A study of the oxidation of the oil by UV-Visible Spectroscopy (UV-VIS) at temperature range of 1151450 C (Saha, 1999).

5) Tensile strength of cellulose insulation paper retrieved from a retired transformer were measured in the cross machine direction (CMD) at temperature range of 129$1660 \mathrm{C}$ and the relationship between tensile strength and molecular weight has been correlated (Hill, 1995).

6) Furan products formed by accelerated ageing of cellulose insulation paper in Shell Diala B transformer insulation oil over the temperature range 115-1450 $\mathrm{C}$ (Saha, 2000) and 129-1660 C and the results have been correlated with those observed for the changes in the molecular weight and tensile strength of the insulation paper (Hill,
1996).

\section{Aging Vial Model}

In order to have better understanding of insulation ageing, dynamic ageing experiment were conducted. In the experimental work, Kraft paper of electrical grade and uninhibited mineral oil Nynas Nytro 11EN was used. The paper was wrapped in several layers around a length of $5 \mathrm{~cm}$ of copper conductor. To dry the paper it was placed in the ageing vial and placed in vacuum oven. The oven was set at $70^{\circ} \mathrm{C}$ and vacuum was applied for overnight. The ageing vial and paper was cooled to room temperature in a desiccators and $100 \mathrm{ml}$ of air saturated oil was added to the vial and sealed immediately using flame torch. In order to have enough paper for DP measurement two pieces of copper conductor wrapped with paper were placed in the ampoule. The ageing vessel had a capacity of $150 \mathrm{ml}$ made from Pyrex glass with $3.8 \mathrm{~cm}$ diameter and $20 \mathrm{~cm}$ length. It had a narrow neck of $1 \mathrm{~cm}$ diameter and $4 \mathrm{~cm}$ length. All ampoules were washed with water rinsed with acetone and dried at $100^{\circ} \mathrm{C}$ before use. The sealed vials were placed in an oven with set temperature of $70^{\circ} \mathrm{C}$. The oven temperature was increased $10^{\circ} \mathrm{C}$ after 24 hours and each day one set of samples were removed until temperature reached $180^{\circ} \mathrm{C}$. Blank sample was also carried out using similar condition for every $10^{\circ} \mathrm{C}$ (Pahlavanpour 2002, 2003).

\section{E. Test Cell Model}

In order to perform the experiments in laboratory a special test cell model has been designed for accelerated thermal and electrical ageing treatment on oil \& paper. The schematic diagram of the test cell is shown in figure 6 . The capacity of the test cell is three liters. A mild steel plate of $3.5 \mathrm{~mm}$ thickness has been used. The inner surface of the test cell has been polished with high temperature resistant enameled paint. The silicon sealing has been provided in between the top cover plate to prevent the leakage of gases at high temperature. When the paper was tested in the presence of oil, the two copper strips covered with paper joined together were placed in the cell. The mineral oil taken conformed to the requirement of IS: 335 and unaged electrical grade paper conformed to IS: 9335 . The temperature control of the oven was within $\pm 2{ }^{0} \mathrm{C}$.

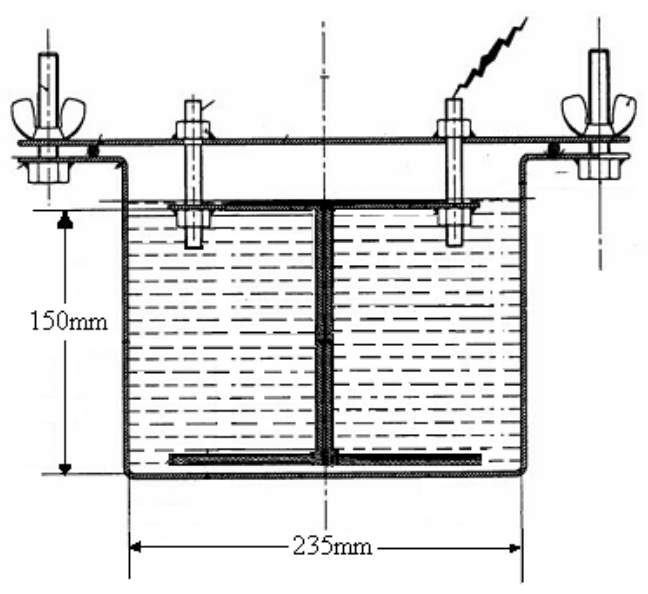

Fig 6: Test Cell Model 
Different thermal and electrical stresses, as per table 5, were used for studying the accelerated thermal and electrical ageing treatment on oil and paper.

TABLE 5. THERmal, Electrical AND AgING ACCELERATED EXPERIMENTS

\begin{tabular}{|c|c|c|}
\hline Temperature $\left({ }^{0} \mathrm{C}\right)$ & Voltage Stress $(\mathrm{KV})$ & Aging time (hours) \\
\hline 120 & $1.0,2.0 \& 2.5$ & $360,720 \& 1440$ \\
\hline 140 & $1.0,2.0 \& 2.5$ & $360,720 \& 1440$ \\
\hline 160 & $1.0,2.0 \& 2.5$ & $360,720 \& 1440$ \\
\hline
\end{tabular}

The thermal and electrical stresses affect the properties of oil and paper insulation used in the transformer. The properties such as furfural analysis, tensile strength, degree of polymerization (DP), dissolved gas analysis (DGA), Breakdown voltage (BDV), resistivity, dissipation factor, viscosity, partial discharge (PD), scanning electron microscopy (SEM) etc. should be effected by the thermal and electrical stresses (Verma, 2005).

\section{CONCLUSION}

It is not possible to perform many tests destructive in nature on power transformer in service. In order to perform these tests, prorated models of power transformers are used in experimental study. Researcher have used various types of model like prototype model, dual temperature aging model, ampoule vial model, aging vial model and test cell model. Basic concept of these models is to study the accelerated thermal, electrical stresses with aging on oil and paper insulation of power transformer.

\section{ACKNOWLEDGMENT}

The authors are thankful to Technology Information Forecasting and Assessment Council and Centers of Relevance \& Excellence (TIFAC-CORE) on Power Transformer Diagnostics and Dr.R.K.Jarial, Assistant Professor and Office-in-charge, HV Lab, NIT Hamirpur for providing necessary infrastructural facilities for carrying out the research work.

\section{REFERENCE}

[1] Dakin T. W., "Electrical Insulation Deterioration Treated as a Chemical Rate Phenomenon," AIEE nansactions, vo1.67, 1948. Summary: Transformer condition monitoring is carried out regularly to establish state of the health of transformer. Based on results corrective actions are taken to preserve and prolong the lifetime of the unit. All insulation materials used in construction o.....

[2] Hill. D. J. T., Le. T. T., Darveniza. M. \& Saha, "A Study of Degradation of cellulosic insulation in a Power Transformer-Part III Degradation Products of Cellulose Paper Insulation," Polymer Degradation and Stability, vo1.51, Issue 2, Feb 1996, pp. 211-218.

[3] Hill. D. J. T., Le. T. T., Darveniza. M. \& Saha. T. K., "A study of Degradation of Cellulosic Insulation Materials in a Power Transformer Part 1: Molecular Weight Study of Cellulose Insulation Paper," Polymer Degradation and Stability, vo1. 48, no. 1, 1995, pp. 79- 87.

[4] Hill D.J.T; Le T.T.; Darveniza M \& Saha T, "A Study of Degradation of Cellulosic Insulation Materials in a Power Transformer-Part 2: Tensile Strength of Cellulose Insulation Paper," Polymer Degradation and Stability, vol.49, no. 3, 1995, pp. 429-435.

[5] McNutt, W.J.; Provost, R.L.; Whearty, R.J, "Thermal life evaluation of high temperature insulation systems and hybrid insulation systems in mineral oil", IEEE Transactions on Power Delivery, vol. 11, Issue 3, July 1996, pp. $1391-1399$.

[6] Moser. H. P. et al., "Application of Cellulosic and Non-cellulosic Materials in Power Transformers," International Conference on Large High Voltage Electric System, CIGRE Proceedings ofthe 31st Session (Paper 12-12), vol.1, 27 August- 4 September, 1986.

[7] Montsinger V. M., "Loading Transformer by Temperature," AIEE Transactions, vol. 49, April 1930.

[8] Oomen T. V. \& Arnold L. N., "Cellulose Insulation Materials Evaluated by Degree of Polymerization Measurements," Proceedings of the 15th Electrical/Electronics Insulation Conference, Chicago, IL, USA, 19-22 Oct. 1981.

[9] Prevost. T. A., Wicks R., Glenn. B., \& Marek R., "Estimation of Insulation life based on a dual temperature aging model", WedimannACTI Inc. Fifth Annual Technical Conference, Albuquerque, NM, Nov. 13-15, 2006.

[10] Pradhan, M.K, "Assessment of the status of insulation during thermal stress accelerated experiments on transformer prototypes", IEEE Transactions on Dielectrics and Electrical Insulation, vol. 13, Issue 1, Feb. 2006, pp. $227-237$.

[11] Pradhan, M.K.; Ramu, T.S, "On the estimation of elapsed life of oilimmersed power transformers", IEEE Transactions on Power Delivery, vol. 20, Issue 3, July 2005, pp. $1962-1969$.

[12] Pradhan, M.K.; Ramu, T.S, "Diagnostic testing of oil-impregnated paper insulation in prorated power transformers under accelerated stress", Conference Record of IEEE International Symposium on Electrical Insulation, 19-22 Sept. 2004, pp. $66-69$.

[13] Pahlavanpour, P.; Eklund; Martins, M.A, "Insulating paper ageing and furfural formation", Proceeding of Electrical Insulation Conference and Electrical Manufacturing \& Coil Winding Technology Conference, 23-25 Sept. 2003, pp. $283-288$.

[14] Pahlavanpour, B.; Martins, M.A.; De Pablo, A, "Experimental investigation into the thermal-ageing of Kraft paper and mineral insulating oil", IEEE International Symposium on Electrical Insulation, 7-10 Apr 2002, pp. 341- 345.

[15] Saha, T.K \& Purkait.P, "Understanding the Impacts of Moisture and Thermal Ageing on Transformer's Insulation by Dielectric Response and Molecular Weight Measurements", IEEE Transactions on dielectric and electrical insulation, vol. 15, Issue 2, April 2008, pp. $568-582$.

[16] Saha. T.K.,Yao. Z.T., Le. T. T, Derveniaa. M. and Hill. D.J.T., "Investigation of Interfacial Polarisation Spectra Parameters for accelerated aged oil-paper insulation and its correlation with molecular weights and furan compounds", 15-201, Cigre Session 2000.

[17] Saha, T.K.; Darveniza, M.; Yao, Z.T.; Hill, D.J.T. \& Yeung, G, "Investigating the effects of oxidation and thermal degradation on electrical and chemical properties of power transformers insulation", IEEE Transactions on power delivery, vol. 14, Issue 4, Oct. 1999 pp. $1359-1367$.

[18] Saha, T.K.; Darveniza, M.; Hill, D.J.T. \& Le, T.T., "Electrical and chemical diagnostics of transformers insulation. B. Accelerated aged insulation samples", IEEE Transactions on power delivery, vol. 12, Issue 4, Oct. 1997, pp. $1555-1561$.

[19] Shroff D. H. \& Stannett A. W., "A Review of Paper Aging in Power Transformers," IEE Proc. , vol. 132, Nov. 1985.

[20] Verma, P.; Roy, M.; Tiwari, R.K. \& Chandra, S, "Generation of furanic compounds in transformer oil under accelerated thermal and electrical stress", Proceeding of Electrical Insulation Conference and Electrical Manufacturing Expo, 23-26 Oct. 2005, pp. 112- 116.

[21] Verma.P, Roy.M, Verma.A \& Bhanot.V \& O.P.Pandey, "Change in Electrical and Chemical properties of transformer oil with accelerated thermal stress and its service life", International Journal of COMADEM, 8(1), 2005 pp. 42-48.

[22] Verma.P, Roy.M, Verma.A \& Bhanot.V, "Assessment of transformer insulation system by evaluating partial discharge and dissolved gas analysis", Journal of Scientific \& Industrial Research, vol.64, April 2005, pp. 262-267.

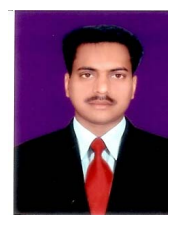

Jashandeep Singh was born in 1978. He obtained his diploma in Electrical Engineering in 1999, B. Tech in Electrical Engineering and M. Tech. in Instrumentation \& Control in 2002 and 2004 respectively. He is presently studying for his Ph.D from the Department of Electrical Engineering (EED) of National Institute of Technology (NIT), Hamirpur. He is working as Research Scholar in 
the EED of NIT, Hamirpur. His research interests are energy management, transformer diagnosis and electrical machines.

Dr. Yog Raj Sood has received his B.E. degree in Electrical Engineering with "Honours" and M.E. in Power System from Punjab Engineering College Chandigarh (U.T.), in 1984 and 1987 respectively. He obtained his Ph.D. from Indian Institute of Technology, Roorkee in 2003. He joined Regional Engineering College Kurukshetra in 1986. He has been working as Professor in the Electrical Engineering Department of National Institute of Technology, Hamirpur (H.P.), India since January 2006. He has published a number of research papers. He is recipient of several commendations, appreciation letters \& awards for his excellent educational and research work. His research interests are in the area of computer applications to power system, deregulation, AI application to power systems, power network optimization, high voltage engineering and non-conventional sources of energy.

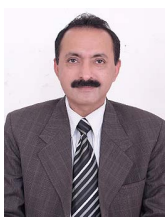

Dr. Piush Verma graduated in 1991 with degree in Electrical Engineering from the Institution of Engineers (India). He received his Master degree in Power Systems with Honors and $\mathrm{Ph}$. D. in Electrical \& Instrumentation Engineering from Thapar University, Patiala, Punjab (India) in 1995 and 2005 respectively. He has over 17 years of experience in Research, Industry and Academia He has been awarded with gold medal for one of the paper by Institute of Engineers, (India). Presently he is Director, Rayat \& Bahra Institute of Engg. \& Bio - Tech., Mohali Campus (Punjab). His research interests are in the area of Transformer Diagnostics study and Non-Conventional Sources of Energy. 